системності творчої роботи з учнями.

Учитель має виходити за межі свого предмета, стимулювати емоційну сферу дітей, здійснювати емоційно-позитивний вплив, мотивувати діяльність, використовувати різноманітні види діяльності на уроці, пов'язувати знання 3 життєвим досвідом дітей та залучати дітей до творчої діяльності через інтегровані творчі завдання.

\title{
Література
}

1. Біла І. Феномен дитячої творчості / І. Біла // Дошкільне виховання. - 2011. - № 1. С. 7-11. 2. Богоявленская Д. Б. Интеллектуальная активность как проблема творчества / Д. Б. Богоявленская. - Ростов-на-Дону: Изд-во Ростовского университета, 1983. - 172 с. 3. Бондаренко Н. Про формування творчої особистості молодшого школяра засобами слова / Н. Бондаренко // Початкова школа. - 1998. - № 9. - С. 22-24. 4. Ковальова В. І. Інтеграція навчального процесу як чинник розвитку пізнавальної активності учнів / В. І. Ковальова // Початкове навчання та виховання. - 2012. - № 16-18. - С. 27-34. 5. Пермяков О. А. Короткий термінологічний словник 3 педагогіки / О.А. Пермяков. - Кривий Ріг : Видавничий дім, 2007. - 116 с. 6. Рибалка В. В. Поняття про творчість, творчу особистість та особистісний підхід до вивчення i розвитку творчого потенціалу молоді // Рибалка В. В. Психологія розвитку творчої особистості. - Київ, 1995. - С. 5-24. 7. Савченко О. Я. Дидактика початкової освіти: [підручник] / Олександра Яківна Савченко. - Київ : Грамота, 2012. - 504 с. 8. Сисосва С. О. Основи педагогічної творчості вчителя / Світлана Олександрівна Сисоєва. - Київ : ІСДОУ, 1994. - 112 с. 9. Стернберг Р. Практический интеллект / Р. Стернберг. - Санкт-Петербург : Питер, 2002.- 272 с. 10. Холодная М. А. Психология интеллекта / М. А. Холодная. - Санкт-Петербург : Питер, 2002. $-272 \mathrm{c}$.

\section{СОЦІОКУЛЬТУРНИЙ ПІДХІД ДО НАВЧАННЯ АНГЛІЙСЬКОЇ МОВИ У ВИЩОМУ НАВЧАЛЬНОМУ ЗАКЛАДІ}

Покорна Л. М. Соціокультурний підхід до навчання англійської мови у вищому навчальному закладі.

У статті аналіз особливостей формування комунікативної компетенції дозволив виокремити соціокультурну компетенцію майбутніх учителів англійської мови в окремий компонент комунікативної компетенції та розглянути їі як цілісну систему, до якої входить країнознавча компетенція, лінгвокраїнознавча компетенція та соціолінгвістична компетенції.

Ключові слова: комунікативна компетенція, соціокультурна компетенція, країнознавча компетенція, лінгвокраїнознавча компетенція, соціолінгвістична компетенція.

Покорная Л. Н. Социокультурный подход к изучению английского языка в высшем учебном заведении.

В статье анализ особенностей формирования коммуникативной компетенции позволил выделить социокультурною компетенцию будущих учителей английского языка в отдельный компонент и рассмотреть её как целостную систему, в которую входят страноведческая компетенция, лингвострановедческая компетенция и социолингвистическая компетенции.

Ключевые слова: коммуникативная компетенция, социокультурная компетенция, 
страноведческая компетенция, лингвострановедческая компетенция, социолингвистическая компетенция.

Pokornaya L. N. Sociocultural approach to learning English language at a higher educational institution.

In the article the analysis of peculiarities of communication competence formation gives the possibility to identify sociocultural competence of future English teachers as a separate component of the communication competence and to consider it as an integral system consisting of the following competences: country studies, linguistic and cultural studies and sociolinguistic.

Key words: communication competence, sociocultural competence, country studies competence, linguistic and cultural country studies competence, sociolinguistic competence.

Питання про країнознавчий, лінгвокраїнознавчий та соціокультурний аспекти навчання іноземних мов, зміст комунікативної компетенції знайшло теоретичне обгрунтування у працях багатьох науковців (М. Аріян, Є. Верещагін, І. Воробйова, Н. Гез, М. Євтух， І. Зимня， Н. Ішханян, В. Костомаров, О. Леонтьєв, Ю. Пассов， Л. Петухова, B. Сафонова, Л. Смелякова, Г. Томахін, В. Топалова, P. Adler, D. Brown, M. Byram, R. Lado та ін.).

Mета статmi - розкрити роль соціокультурної компетенції вчителів іноземної мови в структурі загальної готовності до здійснення педагогічної діяльності.

Вивчення культури у процесі навчання окремих дисциплін робить значний внесок у виховання підростаючого покоління. Предмет «Іноземна мова» посідає в цьому ряді особливе місце. Він не лише ознайомлює з культурою країн, мова яких вивчається, але шляхом порівняння відтінює особливості своєї національної культури загальнолюдськими цінностями. Іншими словами, сприяє вихованню молоді в контексті діалогу культур. Виникає запитання, у чому полягає ця внутрішня необхідність? Справа в тому, що пізнання світу тієї чи іншої людської спільноти, звичаїв, що знайшли своє відображення в культурі, передаються в мові та можуть стати перешкодою під час спілкування представників різних народів. Цей факт добре відомий педагогам та методистам XIX та XX ст. Іще К. Ушинський писав, що найкращий і навіть єдиний спосіб проникнути в характер народу - засвоїти його мову, і чим глибше Ви увійшли в мову народу, тим глибше Ви увійшли в його характер. Представники так званого прямого методу обгрунтували доцільність уведення відомостей про країну, мова якої вивчається, іiі культури у процесі викладання мови, організацію культури, країнознавчих лекцій, що були б доповненням до занять іноземною мовою.

90-і роки минулого століття радикально змінили соціокультурний контекст вивчення мов міжнародного спілкування у Свропі, що не могло не привести до появи нових потреб у вивченні мов і культур. Думка про необхідність культурознавчої освіти засобами іноземної мови поступово починає набувати аксіоматичного звучання. Однак актуальним $є$ питання, яку культурознавчу освіту реально може отримати студент в умовах навчального процесу в різних вищих навчальних закладах? Які можуть бути вимоги до рівня іншомовної соціокультурної компетенції? Якими можуть бути сучасні вимоги до країнознавчого наповнення навчальних програм та навчальної літератури 3 іноземної мови? Що слід розуміти під культурознавством країн, мова яких вивчається? Ці та низка інших питань стоять перед педагогами і відповіді на них не завжди можуть мати однозначний характер.

Однак якщо говорити про культурознавство як про теоретико-прикладну галузь мовної педагогіки, то воно набуває додатково цілий ряд соціально-педагогічних i 
методичних функцій. По-перше, воно вивчає загальнотеоретичні основи розвитку полікультурної мовної особистості у процесі вивчення мов, культур і цивілізацій. По-друге, воно сконцентроване на ціннісно-орієнтаційній основі змісту краєзнавчої освіти засобами одночасного вивчення мов, досліджує діапазон соціалізованого впливу іншомовного навчального спілкування на тих, хто навчається. По-третє, воно визначає принципи культурознавчої освіти засобами вивчення мов з урахуванням соціокультурного контексту вивчення іноземної мови та навчання іноземній мові. По-четверте, на нього покладається зобов'язання звернутися до проблем відбору культурознавчого матеріалу 3 навчальною метою, його методичне структурування для різних освітніх контекстів і розроблення технології оцінювання культурознавчого наповнення навчальної літератури. Саме в мовній педагогіці можна звернутися до проблем побудови багаторівневої моделі культурознавчої освіти й самоосвіти, а також технологій соціокультурної освіти засобами іноземної мови [2, с. 20].

Методичні дослідження в галузі соціокультуралістики створюють основу для розроблення навчальної літератури з країнознавства країн та культурних товариств, мова яких вивчається. До того ж, варто звернути увагу на той факт, що сучасне країнознавство не повинно бути країнознавчо-замкнутим, а розкривати сутність, діалектику взаємодії загальнопланетного та культурознавчого специфічного в бутті людського суспільства та конкретних спілок. У межах соціокультурного підходу до навчання іноземної мови під міжкультурним спілкуванням розуміють функціонально обумовлену комунікативну взаємодію людей, що є носіями різних культурних товариств. Якщо йдеться про іншомовне міжкультурне спілкування, то інструментом постає мова, нерідна для усіх або для деякої частини учасників цієї міжкультурної взаємодії [1, с. 80].

Соціокультурна культурознавча освіта засобами мов (мови міжнаціонального державного спілкування, рідної та іноземної) $є$ необхідною умовою для підготовки до міжкультурного спілкування. Однак воно може бути ефективним лише в тому випадку, якщо цей вид освіти здійснюється 3 урахуванням таких принципів, як принцип дидактичної культуровідповідності, принцип діалогу культур, принцип домінування методично допустимих проблемних культурознавчих завдань [4, с. 78].

Принцип діалогу культур та цивілізацій звертає увагу педагогів на необхідність аналізу культурознавчого, автентичного та частково автентичного матеріалу з точки зору можливостей його використання при моделюванні в аудиторії такого культурного простору, проникнення до якого будується за принципом розширювання кола культур та цивілізацій. Під час розроблення методичної моделі культурознавчого збагачення іншомовної практики цей принцип потребує відповіді на запитання про те, наскільки реально створюються умови для полікультурного та білінгвістичного розвитку мовної особистості студентів, для усвідомлення учнями себе як культурно-історичних суб'єктів, що є носіями не однієї, а цілої низки взаємопов'язаних культур, для підготовки їх до виконання в суспільстві ролі культурного посередника в ситуаціях міжкультурного спілкування, для розвитку в них загальнопланетного мислення й етики поведінки, а також таких якостей, як соціокультурна спостережливість, готовність до спілкування в іншокультурному середовищі, мовленнєвий та соціокультурний такт. Безперечно, принцип діалогу культур та цивілізацій передбачає також, що під час формування культурного простору в умовах іншомовного навчального спілкування використовується культурознавчий матеріал про рідну країну, що дозволяє розвивати у студентів естетику уявлень рідної культури іноземною мовою в іншомовному середовищі, а не лише на їі опору при формуванні уявлень про іншомовне культурне 
товариство, оскільки, як відомо з практики міжкультурного спілкування, нам постійно доводиться не лише інтерпретувати чужу культуру, але й подавати свою власну культуру. Тому рідний світ студента не лише не повинен ігноруватися у процесі вивчення іноземної мови, але й ураховуватися під час відбору культурознавчого наповнення сучасних підручників і посібників з іноземної мови [5, с. 81].

Система навчання іноземної мови $є$ складноорганізованим соціальним об'єктом, аналіз якого супроводжується різними «зрізами» 3 цього об'єкта, кожний із яких є певною картиною цілого. Незалежно від того, який аспект поняття «система навчання іноземної мови» буде предметом розгляду, варто мати на увазі, що в основі функціонування цієї складної соціальної системи лежить не лише взаємодія ії елементів один з одним - система навчання предмета перебуває в найтісніших взаємозв'язках із середовищем, у якому вона $\epsilon$ та розвивається [4, с. 37].

Зміни в соціально-економічній та політичній галузях зумовлюють зміни вимог до системи освіти з іноземної мови, до їі основних складників, до характеру відношень у ній. Соціально-економічні та політичні чинники визначають соціальне замовлення суспільства стосовно рівня та якості володіння його громадянами іноземною мовою.

Соціально-педагогічні чинники відображають рівень усвідомлення всіма, хто безпосередньо працює в галузі навчання, значущості іноземної мови як навчального предмета в загальному контексті освіти. Усе це дозволяє реалізувати соціальне замовлення суспільства в методичних концепціях навчання іноземної мови, програмах, підручниках i посібниках, що використовуються на практиці.

Наступні дві групи чинників перебувають у полі посиленої уваги як теоретиків, так і практиків. Дія цих чинників відображається на всіх рівнях розгляду системи навчання. Соціально-культурні чинники в останній час стали предметом уваги методистів. Окреслені чинники передбачають послідовне урахування соціально-культурного контексту навчання іноземної мови, до якого входять такі категорії, як спільне/відмінне культури країни, мова якої вивчається, та культури учнів; віддаленість/близькість країни, мова якої вивчається, від країни, де вивчається іноземна мова. Одночасно соціокультурні умови визначаються сформованими в суспільстві ставлення до народу, що говорить іноземною мовою, його культури, а також системи культурних та соціальних взаємозв'язків усталених у суспільстві [4, с. 75]. Розвиток комунікативних умінь неможливий без знання мовних засобів спілкування (слова, граматичні явища тощо) та навичок володіння цими засобами в усному та писемному мовленні.

Навчання іноземної мови як засобу міжкультурної комунікації ставить задачу інтегрувати знання, які студент отримує у процесі трансляції мови й культури. Він пізнає іншу дійсність, інші соціальні приклади поведінки, соціально-мовленнєві штампи, порівнює ïx з власним досвідом, отриманим у рідній культурі, учиться розуміти представників інших соціально-культурних спільнот. Іншими словами, його картина світу, сформована в рідній мові, актуалізується й набуває проблемного характеру[3, с. 18].

Соціокультурний компонент змісту освіти покликаний сприяти засвоєнню студентами фонових знань, зрозумілих їх ровесникам за кордоном. Джерелами для цього відбору слугують дитяча, підліткова, юнацька література, мистецтво та знання країни, мова якої вивчається, а також досвід спілкування закордонних студентів з довкіллям. При цьому важливо, щоб соціокультурний компонент змісту навчання не був рекламою чужого образу, способу життя. Його призначення - розширити загальний, соціальний, культурний кругозір молоді, стимулювати їх пізнавальні й інтелектуальні процеси, навчити терпимо ставитися до 
особливостей поведінки представників свого соціуму та іншої культури, об'єктивно оцінювати культурні феномени, що мають місце в різних лінгвокультурних контекстах життєдіяльності.

Одним із ключових понять, що визначають зміст комунікативної компетенції, є «комунікативне вміння» (skill), складниками якого постають «мікровміння» (sub-skill), «комунікативна функція» (function), та «форма вираження функції» (exponent). Спеціально відібраний інвентар функцій і форм їх вираження, що відповідає «просунутому» рівню володіння мовою за класифікацією, викладеною у Загальноєвропейських Рекомендаціях 3 мовної освіти та Українських кваліфікаційних стандартах. Однак необхідно зазначити, що володіння набором функцій і варіантами форм їх вираження само по собі, не підкріплене знаннями про етнокультурну специфіку вживання тих чи інших мовних одиниць, не може забезпечити досягнення необхідного рівня соціокультурної та прагматичної компетенції [5, с. 190].

Виходячи 3 вище сказаного, можна констатувати, що у викладанні іноземних мов цілком виправданим, доцільним, і навіть необхідним $є$ застосування результатів такого напрямку лінгвістичних досліджень, як крос-культурне вивчення мовленнєвих актів. Соціокультурний компонент змісту освіти в навчанні іноземних мов має величезний потенціал для включення учнів до діалогу культур, ознайомлення із здобутками національної культури в розвитку загальнолюдської культури. Лінгвокраїнознавчий аспект, безумовно, сприяє збагаченню предметно-змістового плану мовлення, підвищенню мотивації вивчення іноземних мов, робить значний внесок у виховання, навчання й розвиток особистості засобами іноземної мови, сприяє більш усвідомленому засвоєнню іноземної мови як засобу міжкультурного спілкування.

Отже, в основу структури соціокультурної компетенції майбутніх учителів іноземних мов покладено принцип інтеграції змісту соціокультурної компетенції: знань (країнознавчі, лінгвокраїнознавчі, соціолінгвістичні); умінь та навичок застосовувати ці знання. Відтак, під соціокультурною компетенцією майбутнього вчителя іноземних мов розуміється інтегративна властивість особистості, що виражається в гармонії країнознавчої, лінгвокраїнознавчої, соціолінгвістичної компетенцій, що дозволяють індивідові розуміти закономірності розвитку культури як процесу створення, збереження й трансляції загальнолюдських цінностей, орієнтуватись у традиціях, реаліях, звичаях, духовних цінностях не лише свого народу, але й інших націй, уміти спілкуватись іноземною мовою в сучасному світі, оперуючи культурними поняттями й реаліями різних народів.

\section{Література}

1. Грачева Н. П. Понятие лингвострановедение. Его лингвистические и лингводидактические основы / Н. П. Грачева // Иностранные языки в школе. - 2000. -№ 3. С. 77-80. 2. Державна національна програма «Освіта» (Україна XXI століття). - Київ : Райдуга, 1994. - 62 с. 3. Райхштейн А. Д. Лингвистика и страноведческий аспект в преподавании иностранного языка / А. Д. Райхштейн // Иностранные языки в школе. 1981. - № 4. - C. 13-19. 4. Ashworth Clark I. Stepping stones / Clark I. Ashworth. - Addison Wesley Longman LTD, 1998. - 90 p. 5. Kramsch C. J. Context and culture in language teaching / C. J. Kramsch. - Hong Kong : Oxford University Press, 1996. - 295 p. 